\title{
Neonatal Hypoglycemia, Early-Onset Diabetes and Hypopituitarism Due to the Mutation in EIF2S3 Gene Causing MEHMO Syndrome
}

\author{
J. STANIK ${ }^{1,2,3}$, M. SKOPKOVA ${ }^{2}$, D. STANIKOVA ${ }^{1,2,4}$, K. BRENNEROVA $^{1}$, L. BARAK ${ }^{1}$, \\ L. TICHA ${ }^{1}$, J. HORNOVA ${ }^{1}$, I. KLIMES ${ }^{2}$, D. GASPERIKOVA ${ }^{2}$
}

${ }^{1}$ Department of Pediatrics, Medical Faculty of Comenius University and Children Faculty Hospital, Bratislava, Slovakia, ${ }^{2}$ DIABGENE and Laboratory of Diabetes and Metabolic Disorders, Institute of Experimental Endocrinology, Biomedical Research Center, Slovak Academy of Sciences, Bratislava, Slovakia, ${ }^{3}$ Center for Pediatric Research Leipzig, University of Leipzig, Germany, ${ }^{4}$ Institute of Social Medicine, Occupational Health and Public Health, University of Leipzig, Germany

Received June 14, 2017

Accepted September 21, 2017

On-line January 5, 2018

\begin{abstract}
Summary
Recently, the genetic cause of several syndromic forms of glycemia dysregulation has been described. One of them, MEHMO syndrome, is a rare X-linked syndrome recently linked to the EIF2S3 gene mutations. MEHMO is characterized by Mental retardation, Epilepsy, Hypogonadism/hypogenitalism, Microcephaly, and Obesity. Moreover, patients with MEHMO had also diabetes and endocrine phenotype, but detailed information is missing. We aimed to provide more details on the endocrine phenotype in two previously reported male probands with MEHMO carrying a frame-shift mutation (I465fs) in the EIF2S3 gene. Both probands had a neonatal hypoglycemia, early onset insulindependent diabetes, and hypopituitarism due to dysregulation and gradual decline of peptide hormone secretion. Based on the clinical course in our two probands and also in previously published patients, neonatal hypoglycemia followed by earlyonset diabetes and hypopituitarism may be a consistent part of the MEHMO phenotype.
\end{abstract}

\section{Key words}

MEHMO syndrome • EIF2S3 • Diabetes • Hypopituitarism

\section{Corresponding authors}

D. Gasperikova, DIABGENE and Laboratory of Diabetes and Metabolic Disorders, Institute of Experimental Endocrinology, Biomedical Research Center, Slovak Academy of Sciences, Dubravska cesta 9, 84505, Bratislava, Slovakia. E-mail: daniela.gasperikova@savba.sk and J. Stanik, Department of Pediatrics, Medical Faculty of Comenius University, Limbova 1, 83340 Bratislava, Slovakia. E-mail: juraj.stanik@savba.sk

\section{Introduction}

Monogenic diabetes is a heterogeneous group of disorders caused by a mutation of a single gene involved to the insulin secretion or action (Rubio-Cabezas et al. 2014). The highest prevalence of monogenic diabetes is in patients with neonatal ( $<6$ months) and infancy onset ( $<1$ year) diabetes mellitus (Rubio-Cabezas et al. 2014, Stanik et al. 2007). There are several subtypes of monogenic neonatal and infancy onset diabetes, i.e. 1) disorders with abnormal pancreatic development including pancreatic agenesis and imprinting abnormalities, 2) disorders with abnormal $\beta$-cell function, particularly including INS, KCNJ11, and $A B C C 8$ mutations, and 3 ) disorders causing destruction of $\beta$-cells by dysfunction in the unfolded protein response pathway (Walter and Ron 2011, Wang and Kaufman 2012) including recently published Ile465Serfs mutation in the EIF2S3 gene causing the MEHMO syndrome (Skopkova et al. 2017). The EIF2S3 gene encodes the $\gamma$ subunit of eukaryotic translation initiation factor 2 (eIF2), crucial for initiation of protein synthesis and regulation of the integrated stress response. MEHMO syndrome 
(OMIM\# 300148) is characterized by X-linked intellectual disability, epileptic seizures, hypogonadism, hypogenitalism, microcephaly, and obesity (LeshinskySilver et al. 2002). Diabetes or endocrine phenotypes have not been included to the main signs of the MEHMO syndrome. Nevertheless, majority of the previously published MEHMO patients had hypoglycemia or diabetes and/or endocrine phenotype, but detailed information is missing. Therefore, we aimed to provide more details on the endocrine phenotype in two male probands with MEHMO carrying a frame-shift mutation (I465fs) in the EIF2S3gene (Skopkova et al. 2017).

\section{Patients and Methods}

We refer on two probands with MEHMO syndrome of Slovak origin. Glucose, serum C-peptide, and hormone levels were measured in local labs by standardized methods (Stanikova et al. 2015). HbA1c was evaluated from whole blood by LPLC DiaSTAT analyzer (Bio-Rad, Hercules, USA). All steps of this study were approved by the Faculty Hospital Ethics Committees in Bratislava. Parents of both patients had signed the informed consent.

\section{Results}

Diabetes and endocrine phenotypes of the affected probands with MEHMO syndrome are summarized in Table 1.

\section{Patient 1 (MEHMO syndrome with diabetes and panhypopituitarism)}

The proband is a second child of nonconsanguineous parents of Slovak origin and the only male offspring in the mother's family. His mother who carried the same EIF2S3 gene mutation as her son had sideroblastic anemia; father and older sister are healthy. The proband had prenatally diagnosed microcephaly at $28^{\text {th }}$ week of gestation. He was delivered in $39+6$ gestational week with birth length of $47 \mathrm{~cm}$ (-2.0 SDS) and weight $2,920 \mathrm{~g}(-1.4 \mathrm{SDS})$ and head circumference $32 \mathrm{~cm}$ (-2.6 SDS). Diagnosis of MEHMO was made at the age of 10 months based on the microcephaly, unstable partial complex epileptic seizures resistant to anticonvulsives, hypogenitalism, severe mental and motor delay, central obesity, and typical dysmorphic features (for photo see Skopkova et al. 2017). Currently he is 6 years old.
Glycemia and diabetes phenotype

Hypoglycemia $<1 \mathrm{mmol} / 1$ firstly occurred at birth and was corrected with glucose infusion. Hypoglycemia $(2.6 \mathrm{mmol} / \mathrm{l})$ reoccurred at the age of 3 months when he was admitted to the hospital with lethargy, vomiting and hypotrophy (weight of 3,830 g, -2.9 SDS). Insulin and C-peptide serum levels were in normal range (Table 1$)$ at that time. Diabetes $(2 \mathrm{~h}$ oral glucose tolerance test glycemia $14 \mathrm{mmol} / \mathrm{l}$; HbA1c $7.5 \%$; $58 \mathrm{mmol} / \mathrm{mol}$ ) was diagnosed at the age of 10 months with mild polyuria but without ketoacidosis $(\mathrm{pH} 7.37$, $\left.\mathrm{HCO}_{3} \quad 26.1 \mathrm{mmol} / \mathrm{l}\right)$. Type 1 diabetes specific autoantibodies were negative. Fasting C-peptide was within normal range for normoglycemic subjects at the point of diagnosis, but decreased over the time (Table 1). The proband was treated by three daily doses with both regular and NPH insulin injections since the age of 1 year. Despite intensive glycemic monitoring he had poor glycemic control with large glycemic excursions, particularly during respiratory infections. The proband was lethargic in euglycemia and needed target glycemia levels between $10-15 \mathrm{mmol} / \mathrm{l}$ to be awake.

\section{Endocrine phenotype}

Panhypopituitarism with growth hormone deficiency, central hypothyroidism, central hypocorticism, low prolactin levels, and low gonadotropin levels with micropenis and cryptorchism was diagnosed at the age of 9 months. Since then he has been treated with substitution therapy of L-thyroxin and cortisol. Most of the peptide hormone levels decreased over the time (Table 1). The brain MRI at the age of 4 months showed a normally developed pituitary gland without any pathological changes. Other features: he suffers from recurrent respiratory tract infections.

\section{Patient 2 (MEHMO syndrome with diabetes and partial hypopituitarism)}

The second proband is a first child of non-consanguineous parents of Slovak origin, and he was born in $40+0$ gestational week with length of $49 \mathrm{~cm}$ (-0.95 SDS) and weight 2,440 g (-2.65 SDS), and head circumference $29 \mathrm{~cm}$ (-5.1 SDS). MEHMO features were very similar to the first proband (Skopkova et al. 2017) including the unstable epileptic seizures resistant to anticonvulsives. The proband inherited the EIF2S3 gene mutation from his asymptomatic mother. 


\section{Glycemia and diabetes phenotype}

The second proband had also period of neonatal hypoglycemia corrected with glucose infusion. He was diagnosed with diabetes (fasting glycemia $14.7 \mathrm{mmol} / \mathrm{l}$; HbAlc $8.7 \%(72 \mathrm{mmol} / \mathrm{mol}))$ at the age of 10 months without ketoacidosis. Type 1 diabetes specific autoantibodies were negative. Fasting C-peptide was within the normal range for normoglycemic subjects at the point of diagnosis, but decreased over the time. The proband was treated with three daily insulin injections $(<0.3 \mathrm{U} / \mathrm{kg} /$ day $)$, but did not achieve good glycemic control (Table 1).

\section{Endocrine phenotype}

Partial panhypopituitarism with growth hormone deficiency, low prolactin levels, low gonadotropin levels with micropenis and cryptorchism was diagnosed at the age of 9 months. The decline of peptide hormone levels with aging was similar to Patient 1 (Table 1).

The second proband died at the age of 3.5 years because of infection and cardiorespiratory failure.

\section{Discussion}

We reported on detailed diabetes and endocrine phenotype in two male probands with the MEHMO syndrome. Both patients developed non-autoimmune infant-onset diabetes with decline of endogenous insulin production with age. Moreover, one of them had decline also of all hypophyseal peptide hormones; the second proband had impaired growth, thyroidal, and prolactin axis (but not ACTH production). The decline of the peptide hormone levels could be explained by the severe impairment of protein synthesis caused by the causal Ile465Serfs mutation in the EIF2S3 gene (Skopkova et al. 2017). All the patients carrying this mutation had similar phenotype including growth retardation and dysregulation of insulin secretion (Skopkova et al. 2017, Moortgat et al. 2016). In both our patients, neonatal hypoglycemia preceded diabetes onset later during the life. This is similar to congenital hyperinsulinism and maturity-onset diabetes caused by dysregulation of insulin secretion due to mutations in genes $H N F 1 A$ and HNF4A (Stanescu et al. 2012, Rozenkova et al. 2015). Nevertheless, in case of MEHMO, also growth hormone deficiency could participate to the pathogenesis of hypoglycemia. Earlyonset diabetes and endocrine symptomatology can also be seen in majority of other disorders caused by increased endoplasmic reticulum stress or a dysfunction in the unfolded protein response pathway, i.e. syndromic form of intellectual disability and diabetes caused by mutations in the PPP1R15B (Kernohan et al. 2015, Abdulkarim et al. 2015), Wolcott-Rallison syndrome caused by mutations of the EIF2AK3 gene (Delepine et al. 2000), Wolfram syndrome caused by mutations in the WFS1 gene (Fonseca et al. 2005), diabetes and multisystemic neurodegeneration caused by mutations of the DNAJC3 (Synofzik et al. 2014), and Microcephaly, Epilepsy, and Diabetes Syndrome (MEDS) caused by mutations of the IER3IP1 gene (Abdel-Salam et al. 2012).

In conclusion, we reported on two patients with MEHMO syndrome with neonatal hypoglycemia followed by early onset diabetes, and hypopituitarism presumably due to dysregulation of protein synthesis and gradual decline of peptide hormone secretion. The genetic analysis of genes involved in protein translation and its regulation needs to be considered in patients with syndromic forms of diabetes and endocrine related syndromes.

\section{Conflict of Interest}

There is no conflict of interest.

\section{Acknowledgements}

This work was supported by research grants supported by the Research and Development Operational Programme and funded by the ERDF (Transendogen/26240220051), and Slovak Research and Development Agency APVV 0107-12 and VEGA 2/0083/17. J.S. was supported by ESPE (European Society for Pediatric Endocrinology) Research Fellowship. We are grateful to physicians of the Pediatric Clinics in Bratislava and Banska Bystrica in Slovak Republic. 


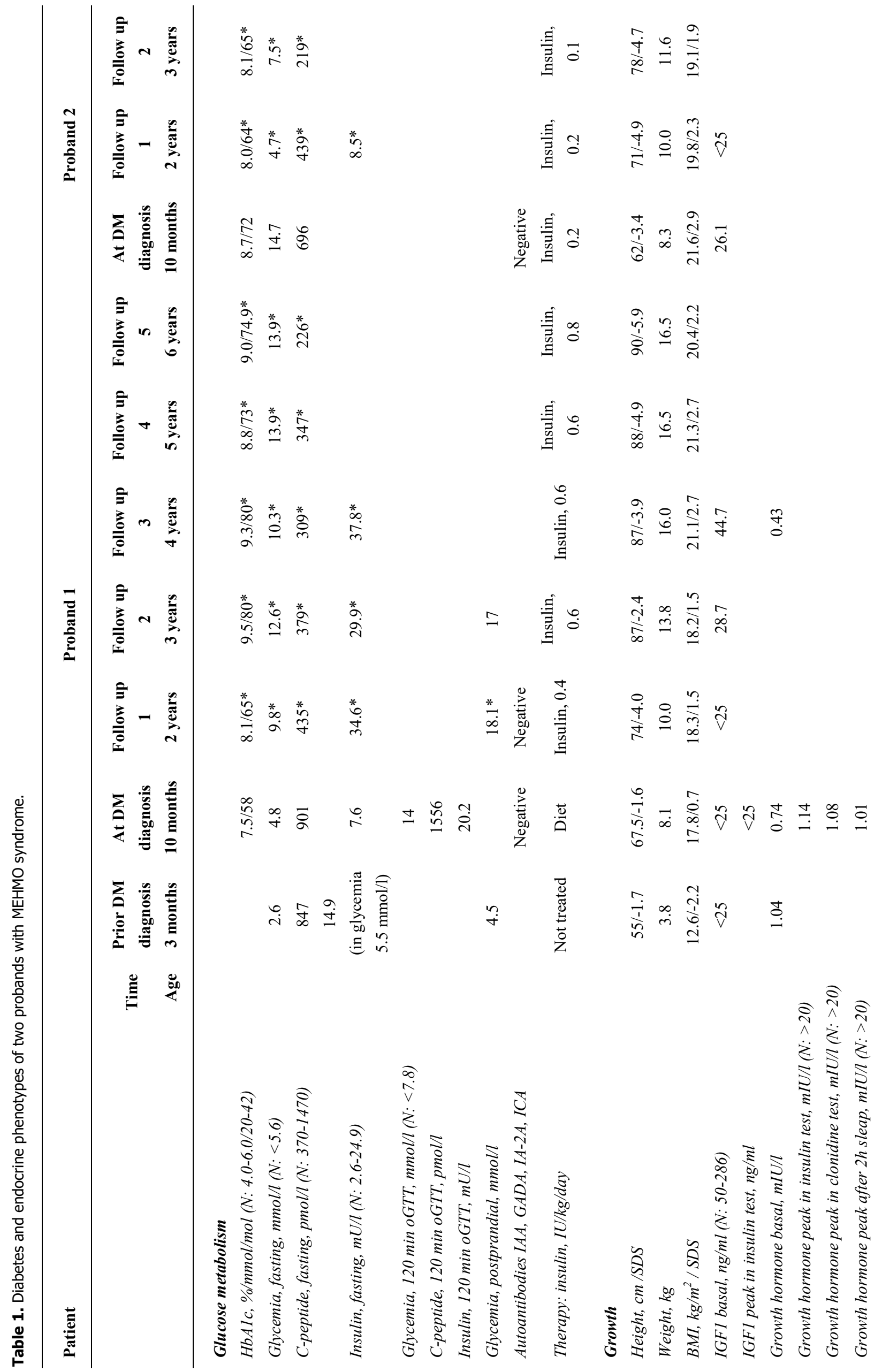




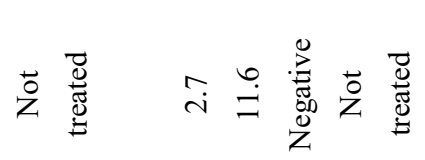

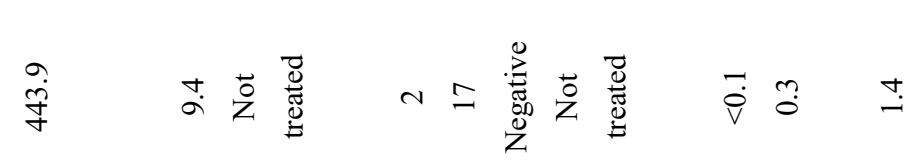

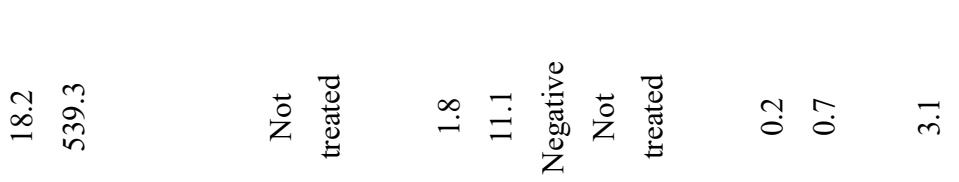

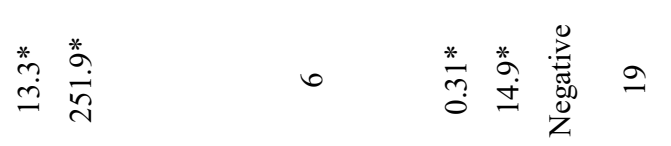

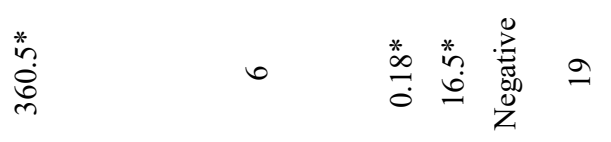

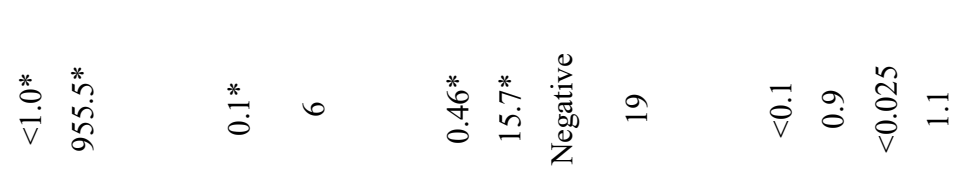

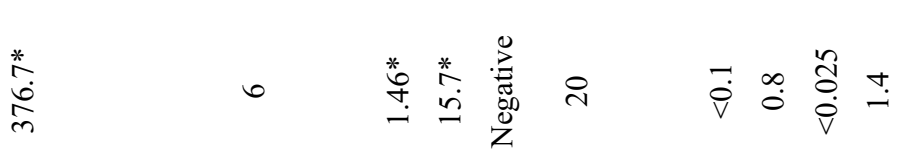

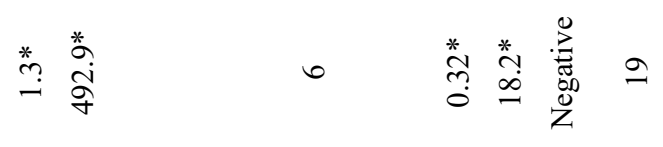

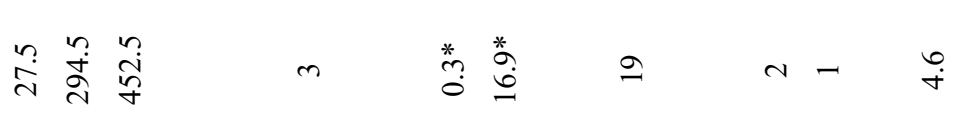

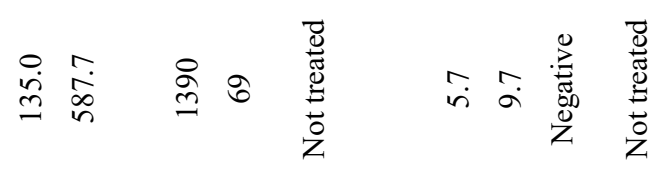

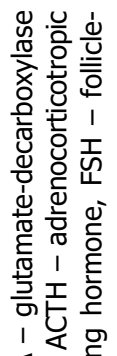

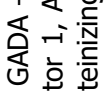

$$
\begin{aligned}
& \text { 可通 }
\end{aligned}
$$

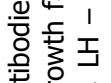

$$
\begin{aligned}
& \text { 苋 응 } \\
& \text { 苧辛 은 } \\
& \text { 焉 } \\
& \text { 额焉保 } \\
& \text { 空它 }
\end{aligned}
$$

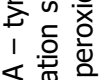

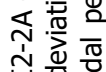

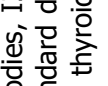

$$
\begin{aligned}
& \text { 要焉 }
\end{aligned}
$$

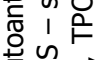

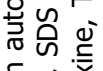

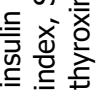

$$
\begin{aligned}
& \text { 它兽 } \\
& \text { 岛高安 }
\end{aligned}
$$

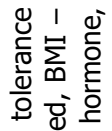

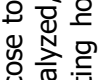

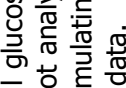

$$
\begin{aligned}
& \text { 중 든 } \\
& 1 \frac{1}{2} \\
& \text { 이에 }
\end{aligned}
$$

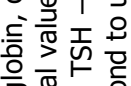

$$
\begin{aligned}
& \text { 음 }
\end{aligned}
$$

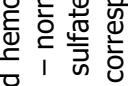

$$
\begin{aligned}
& \text { 焉之误 }
\end{aligned}
$$

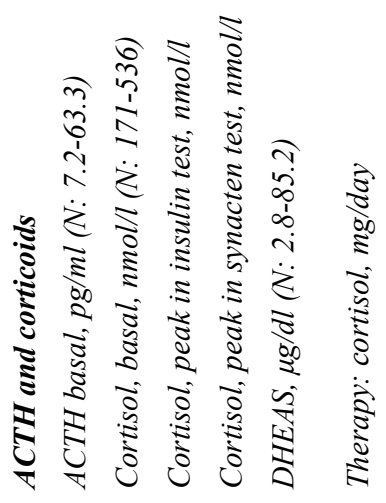

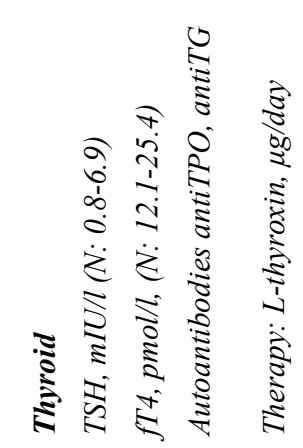

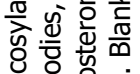

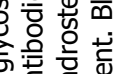

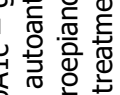

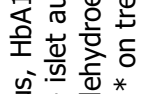

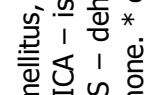

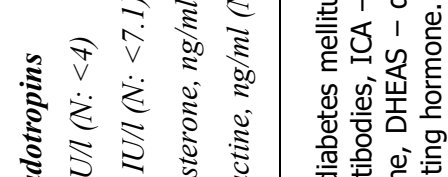

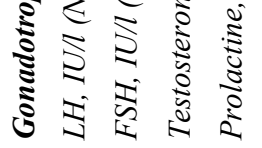




\section{References}

ABDEL-SALAM GM, SCHAFFER AE, ZAKI MS, DIXON-SALAZAR T, MOSTAFA IS, AFIFI HH, GLEESON JG: A homozygous IER3IP1 mutation causes microcephaly with simplified gyral pattern, epilepsy, and permanent neonatal diabetes syndrome (MEDS). Am J Med Genet A 158A: 2788-2796, 2012.

ABDULKARIM B, NICOLINO M, IGOILLO-ESTEVE M, DAURES M, ROMERO S, PHILIPPI A, SENEE V, LOPES M, CUNHA DA, HARDING HP, DERBOIS C, BENDELAC N, HATTERSLEY AT, EIZIRIK DL, RON D, CNOP M, JULIER C: A missense mutation in PPP1R15B causes a syndrome including diabetes, short stature, and microcephaly. Diabetes 64: 3951-3962, 2015.

DELEPINE M, NICOLINO M, BARRETT T, GOLAMAULLY M, LATHROP GM, JULIER C: EIF2AK3, encoding translation initiation factor 2-alpha kinase 3, is mutated in patients with Wolcott-Rallison syndrome. Nat Genet 25: 406-409, 2000.

FONSECA SG, FUKUMA M, LIPSON KL, NGUYEN LX, ALLEN JR, OKA Y, URANO F: WFS1 is a novel component of the unfolded protein response and maintains homeostasis of the endoplasmic reticulum in pancreatic beta-cells. J Biol Chem 280: 39609-39615, 2005.

KERNOHAN KD, TÉTREAULT M, LIWAK-MUIR U, GERAGHTY MT, QIN W, VENKATESWARAN S, DAVILA J; CARE4RARE CANADA CONSORTIUM, HOLCIK M, MAJEWSKI J, RICHER J, BOYCOTT KM: Homozygous mutation in the eukaryotic translation initiation factor 2alpha phosphatase gene, PPP1R15B, is associated with severe microcephaly, short stature and intellectual disability. Hum Mol Genet 24: 6293-6300, 2015.

LESHINSKY-SILVER E, ZINGER A, BIBI CN, BARASH V, SADEH M, LEV D, SAGIE TL: MEHMO (Mental retardation, Epileptic seizures, Hypogenitalism, Microcephaly, Obesity): a new X-linked mitochondrial disorder. Eur J Hum Genet 10: 226-230, 2002.

MOORTGAT S, DESIR J, BENOIT V, BOULANGER S, PENDEVILLE H, NASSOGNE MC, LEDERER D, MAYSTADT I: Two novel EIF2S3 mutations associated with syndromic intellectual disability with severe microcephaly, growth retardation, and epilepsy. Am J Med Genet A 170: 2927-2933, 2016.

ROZENKOVA K, MALIKOVA J, NESSA A, DUSATKOVA L, BJORKHAUG L, OBERMANNOVA B, DUSATKOVA P, KYTNAROVA J, AUKRUST I, NAJMI LA, RYPACKOVA B, SUMNIK Z, LEBL J, NJOLSTAD PR, HUSSAIN K, PRUHOVA S: High incidence of heterozygous ABCC8 and HNF1A mutations in Czech patients with congenital hyperinsulinism. J Clin Endocrinol Metab 100: E1540-E1549, 2015.

RUBIO-CABEZAS O, HATTERSLEY AT, NJOLSTAD PR, MLYNARSKI W, ELLARD S, WHITE N, CHI DV, CRAIG ME, INTERNATIONAL SOCIETY FOR PEDIATRIC AND ADOLESCENT DIABETES: ISPAD Clinical Practice Consensus Guidelines 2014. The diagnosis and management of monogenic diabetes in children and adolescents. Pediatr Diabetes 15 (Suppl 20): 47-64, 2014.

SKOPKOVA M, HENNIG F, SHIN BS, TURNER CE, STANIKOVA D, BRENNEROVA K, STANIK J, FISCHER U, HENDEN L, MULLER U, STEINBERGER D, LESHINSKY-SILVER E, BOTTANI A, KURDIOVA T, UKROPEC J, NYITRAYOVA O, KOLNIKOVA M, KLIMES I, BORCK G, BAHLO M, HAAS SA, KIM JR, LOTSPEICH-COLE LE, GASPERIKOVA D, DEVER TE, KALSCHEUER VM: EIF2S3 mutations associated with severe X-linked intellectual disability syndrome MEHMO. Hum Mutat 38: 409-425, 2017.

STANESCU DE, HUGHES N, KAPLAN B, STANLEY CA, DE LEON DD: Novel presentations of congenital hyperinsulinism due to mutations in the MODY genes: HNF1A and HNF4A. J Clin Endocrinol Metab 97: E2026-E2030, 2012.

STANIK J, GASPERIKOVA D, PASKOVA M, BARAK L, JAVORKOVA J, JANCOVA E, CILJAKOVA M, HLAVA P, MICHALEK J, FLANAGAN SE, PEARSON E, HATTERSLEY AT, ELLARD S, KLIMES I: Prevalence of permanent neonatal diabetes in Slovakia and successful replacement of insulin with sulfonylurea therapy in KCNJ11 and ABCC8 mutation carriers. J Clin Endocrinol Metab 92: 1276-1282, 2007.

STANIKOVA D, SUROVA M, TICHA L, PETRASOVA M, VIRGOVA D, HUCKOVA M, SKOPKOVA M, LOBOTKOVA D, VALENTINOVA L, MOKAN M, STANIK J, KLIMES I, GASPERIKOVA D: Melanocortin-4 receptor gene mutations in obese Slovak children. Physiol Res 64: 883-890, 2015. 
SYNOFZIK M, HAACK TB, KOPAJTICH R, GORZA M, RAPAPORT D, GREINER M, SCHONFELD C, FREIBERG C, SCHORR S, HOLL RW, GONZALEZ MA, FRITSCHE A, FALLIER-BECKER P, ZIMMERMANN R, STROM TM, MEITINGER T, ZUCHNER S, SCHULE R, SCHOLS L, PROKISCH H: Absence of BiP co-chaperone DNAJC3 causes diabetes mellitus and multisystemic neurodegeneration. Am J Hum Genet 95: 689-697, 2014.

WALTER P, RON D: The unfolded protein response: from stress pathway to homeostatic regulation. Science 334: 1081-1086, 2011.

WANG S, KAUFMAN RJ: The impact of the unfolded protein response on human disease. J Cell Biol 197: 857-867, 2012. 